Revue Française de Civilisation Britannique

\title{
Towards a New Health Deal for the North of England?
}

Santé: Vers un New Deal pour le Nord de l'Angleterre?

Louise Dalingwater

\section{(2) OpenEdition}

\section{Journals}

Electronic version

URL: http://journals.openedition.org/rfcb/5264

DOI: $10.4000 /$ rfcb.5264

ISSN: 2429-4373

Publisher

CRECIB - Centre de recherche et d'études en civilisation britannique

Electronic reference

Louise Dalingwater, «Towards a New Health Deal for the North of England? », Revue Française de Civilisation Britannique [Online], XXV-2 | 2020, Online since 25 May 2020, connection on 27 May 2020. URL : http://journals.openedition.org/rfcb/5264 ; DOI : https://doi.org/10.4000/rfcb.5264

This text was automatically generated on 27 May 2020

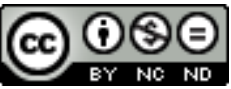

Revue française de civilisation britannique est mis à disposition selon les termes de la licence Creative Commons Attribution - Pas d'Utilisation Commerciale - Pas de Modification 4.0 International. 


\section{Towards a New Health Deal for the North of England?}

Santé: Vers un New Deal pour le Nord de l'Angleterre?

Louise Dalingwater

\section{Introduction}

1 Tackling health inequalities has become one of the key focuses of public health policy over recent years. According to the 2010 Marmot review, not only is there a strong social justice case for reducing health inequalities, but also an economic one, since these disparities are estimated to cost over $£ 30$ billion a year in lost productivity and welfare costs. ${ }^{1}$ Health inequalities refer to differences between people or groups due to social, geographical, biological or other factors. Health coverage is universal in England and close to full coverage in many areas of public health. The founding principles of the NHS are that public health services should be free at the point of use and that health inequalities are undesirable because they are unfair or unjust. Yet, despite universal coverage of health services and the equity principles behind public health in the UK, nowhere is the North-South divide more apparent than in the area of health.

Since the 1960s, the South has consistently outperformed the North in terms of health outcomes in all areas (life expectancy, ill health, chronic disease...). Poor health is associated with socio-economic status, which is one of the main reasons why the North of England is at a disadvantage, with a higher number of 130s suffering from multiple deprivation. This paper will thus compare health inequalities between the North and South and review the literature on predictors of health inequalities in England. It will then review policy since the late 1970s to improve health service delivery in the North of England. In particular, it will consider to what extent public policy has mitigated health inequalities in across England in the age of austerity, and whether there is a difference in performance between health care providers depending on the locality. ${ }^{2}$ 


\section{Equality, Equity and Health Services}

3 When considering the differences in health performance across regions and formulating policy for the North, it is important to take into consideration equity of supply for allocating resources to the region. This is all the more so the case in health because equity is a guiding principle of health policy in Britain and this is also true of most other health care systems in the world. It is however very difficult to measure health equity, especially to distinguish between equity and equality. The essential difference is that equity is equivalent to fairness in the distribution of health care among the population, which is different from equality whereby everybody has a fair share of health care services irrespective of need. There are however different interpretations of equity. Equity may be described as equal use of health services for equal need, equal use of health services according to willingness to pay for that use, equal health outcomes for equal merit, equal health care payment by people according to ability to pay for that health care. ${ }^{3}$ Equity is therefore very much open to interpretation. Other principles may go against the notion of equity. Indeed, the utilitarian principle states that one should maximise society's welfare even if that means creating inequalities. The laissez-faire principle on the other hand considers that there is equity if there are fair-trading regimes, even though this may produce significant inequalities. There is therefore significant conflict between equity, equality principles and economic theory that overrides these principles because the conceptualisation of both notions is essentially normative, based on individual or collective value judgments. There are however three main areas in which the principle of equity is often considered: funding of health care, distribution of health care and distribution of health. The guiding principles of the NHS have generally been that equity should be upheld in these three areas and equity within this institution is interpreted as equal use of health services for equal need irrespective of the ability to pay: "The NHS is a great national institution. The principles it was founded on are as important now as they were then: free at the point of use and available to everyone based on need, not ability to pay." ${ }^{4}$

4 After evaluating general inequalities in the regions, this paper will focus particularly on equity in terms of health care distribution. Equity, fairness and social justice are promoted as the founding principles of the NHS, but the question is whether the organisation achieves equity in practice, especially among those socio-economic groups in the North of England that suffer from significant health inequalities. It is first, however, important to consider inequalities in health outcomes between the North and South before considering whether policy can mitigate these disparities.

\section{Inequalities in health outcomes between the North and South}

Inequalities in health outcomes emerged with the rise and fall of industry in the Northern regions. During the industrial revolution, mining and heavy industry was predominantly located in the north. Ill health, which was prevalent in these industries in the North, continued to persist in the local population even after the closure of many mines and factories from the 1960s onwards. 
6 The former industrialised areas of the North still have a lower life expectancy than elsewhere: lower than three years on average. ${ }^{5}$ Research has shown that premature mortality continues to be more prevalent in the North. According to Buchan et al., from 1965 to 2010, premature mortality (deaths per 10000 aged 75 years or under) fell sharply from 64 to 28 in southern England compared with 72 to 35 in northern England. While for most age groups, excess mortality remained consistent for the period 1965 to 2015 in the North, the 25-34 and 35-44 age groups experienced a sharp increase in excess mortality here, especially between the latter period of the study from 1995 to 2015: an increase from $2.2 \%$ (95\% CI ${ }^{6}-3.2 \%$ to $7.6 \%$ ) to $29.3 \%$ (95\% CI $21.0 \%$ to $37.6 \%$ ); and $3.3 \%$ ( $95 \% \mathrm{CI}-1.0 \%$ to $7.6 \%)$ to $49.4 \%$ (95\% CI $42.8 \%$ to $55.9 \%$ ), respectively. The Northern mortality rate increased for the (ages 25-34) or plateaued (ages 35-44) from the mid-1990s while the mortality rate in the South declined on the whole. ${ }^{7}$

In 2016, the Office for National Statistics (ONS) published a report which also drew a rather gloomy outlook for the North of England. Since the national statistics body started to collect data on local area life expectancy in the 1840s, little has changed. Southern areas still outperform northern areas in life expectancy. In 1991-1993, East Dorset (South West) reported the highest male and female life expectancy and Blackpool (North West), the lowest. In 2017, Kensington and Chelsea (in the South-East) were reported to have the highest life expectancy ( 83.3 years for newborn baby boys and 86.7 years for baby girls), whereas Blackpool and Middlesbrough (in the North) had the lowest life expectancies for boys (Blackpool, 74.7 years) and for girls (Middlesbrough, 79.8 years). While all local areas have experienced an increase in life expectancy, inequalities between performance for the lowest and highest life expectancy have widened, with the majority of local areas in England with the lowest life expectancy to be found in the North East and North West. ${ }^{8}$ Not only does the North fare badly in terms of life expectancy compared to the Southern regions, but it also reports a reduced number of years living in good health as the table below shows. ${ }^{9}$

\begin{tabular}{|c|c|c|c|c|c|c|c|}
\hline \multicolumn{8}{|l|}{ England } \\
\hline English region & LE (years) & HLE (years) & $\begin{array}{r}\text { Lower } 95 \% \\
\text { confidence } \\
\text { interval }\end{array}$ & $\begin{array}{r}\text { Upper } 95 \% \\
\text { confidence } \\
\text { interval }\end{array}$ & $\begin{array}{r}\text { Proportion of } \\
\text { life spent in } \\
\text { "Good" health } \\
(\%)\end{array}$ & LE rank & HLE rank \\
\hline \multicolumn{8}{|l|}{ Males } \\
\hline South East & 80,5 & 65,9 * & 65,5 & 66,3 & 81,8 & 1 & 1 \\
\hline South West & 80,2 & 65,1 * & 64,6 & 65,6 & 81,2 & 4 & 2 \\
\hline East of England & 80,4 & 65,0 * & 64,4 & 65,5 & 80,7 & 2 & 3 \\
\hline London & 80,3 & 64,0 & 63,5 & 64,5 & 79,6 & 3 & 4 \\
\hline East Midlands & 79,4 & 62,7 ** & 62,1 & 63,3 & 79,0 & 5 & \\
\hline West Midlands & 78,9 & 62,4 ** & 61,9 & 62,9 & 79,2 & 6 & 6 \\
\hline Yorkshire and The Humber & 78,7 & 61,4 ** & 60,9 & 61,9 & 78,0 & 7 & 7 \\
\hline North West & 78,1 & $61,1 * *$ & 60,6 & 61,5 & 78,2 & 8 & 8 \\
\hline North East & 78,0 & $59,7 *$ & 59,1 & 60,2 & 76,5 & 9 & 9 \\
\hline England & 79,5 & 63,4 & 63,3 & 63,6 & 79,7 & & \\
\hline \multicolumn{8}{|l|}{ Females } \\
\hline South East & 84,0 & $66,6^{*}$ & 66,1 & 67,1 & 79,3 & 2 & 1 \\
\hline East of England & 83,8 & 66,0 * & 65,4 & 66,6 & 78,7 & 4 & 2 \\
\hline South West & 83,9 & 65,6 * & 65,0 & 66,1 & 78,1 & 3 & 3 \\
\hline London & 84,2 & 64,1 & 63,6 & 64,7 & 76,2 & 1 & 4 \\
\hline East Midlands & 83,0 & 63,5 & 62,8 & 64,1 & 76,4 & 5 & \\
\hline West Midlands & 82,9 & 62,5 ** & 62,0 & 63,1 & 75,5 & 6 & 6 \\
\hline Yorkshire and The Humber & 82,4 & 61,8 ** & 61,2 & 62,4 & 75,0 & 7 & 7 \\
\hline North West & 81,9 & 61,8 ** & 61,3 & 62,2 & 75,5 & 8 & \\
\hline North East & 81,7 & 59,8 * & 59,2 & 60,4 & 73,2 & 9 & 9 \\
\hline England & 83,2 & 64,0 & 63,8 & 64,2 & 76,9 & & \\
\hline \multicolumn{8}{|c|}{$\begin{array}{l}\text { Source: Office for National Statistics } \\
\text { Notes: } \\
\text { 1. Excludes residents of communal establishments except NHS housing and students in halls of residence where inclusion takes place at their } \\
\text { parents' address. } \\
\text { 2. Regions are presented by gender and have been ranked at the England level, based on HLE to more than one decimal place. Their respective } \\
\text { rankings within England are also shown. } \\
\text { 3. Figures may not sum due to rounding. } \\
\text { 4. * denotes that the region HLE estimate is significantly higher than the England HLE estimate at the } 95 \% \text { confidence level. } \\
\text { 5** denotes that the region HLE estimate is significantly lower than the England HLE estimate at the } 95 \% \text { confidence level. } \\
\text { 6. The significance test refers to a one tailed Z test of the difference of the estimates as detailed in Jagger et al., (2007) }\end{array}$} \\
\hline
\end{tabular}


Moreover, according to research carried out by researchers at the University of Liverpool, there are 1.5 million more premature deaths in the North..$^{10}$ The gap between the North of England and the rest of the country in terms of health inequalities has thus continued to widen for the last four decades and over successive governments.

\section{Determinants of health inequalities}

Substantial research has been carried out to determine health disparities between the regions in an attempt to reduce these inequalities. One of the key determinants identified by researchers in the field over several decades is the influence of low income on health. However, other predictors are also relevant.

\section{Socio-economic status}

Richard Wilkinson $(1986,1991,1994,1996,1999,2003,2005,2008)^{11}$ clearly established links between income inequality and life expectancy. His research reveals how serious health inequalities are due to low social status. This has been supported by a number of other studies on the subject. Michael Marmot's work ${ }^{12}$ also shows that those with low status jobs are more at risk from ill health. Growing inequality in income has thus produced growing inequalities in health. The least deprived can expect to lead $80 \%$ of their lives in good health compared to $70 \%$ for the most deprived..$^{13}$

Bartley and Blane established four major models to explain how social class can lead to inequalities in health ${ }^{14}$ :

12 The Behavioural model: Social class will determine whether an individual's way of life is health damaging or health promoting according to dietary choices, consumption of drugs, alcohol and tobacco, active leisure time pursuits, and use of immunisation, contraception and antenatal services. Nevertheless, long-term studies (such as the Whitehall study $)^{15}$ have found that these differences can only account for one-third of social class differences in mortality. A study by Law and Morris ${ }^{16}$ looking at the factors responsible for differences in mortality between the North and South concluded that while deprivation was the overriding factor, excess mortality was also linked to heavy smoking (in $85 \%$ of cases) and heavy alcohol consumption (but only in $6 \%$ of cases).

The Materialist model: Poverty leads to greater health hazards. Those suffering from multiple deprivation will most likely be living in polluted environments: that is in inner cities, with greater air pollution and damp housing. The Black Report ${ }^{17}$ argued that this was the most important reason for social class differences in health.

The Psycho-social model: In the more disadvantaged groups, stress may be caused by social stigma or by imbalance between effort and reward; those in these groups may work in jobs where demands are high and control is low. Such stressful working conditions have been linked to high blood pressure, fibrinogen and a more adverse blood fat profile.

15 The Life-course model: Health is a reflection of the patterns of social, psycho-social and biological advantages and disadvantages experienced by an individual over time. Disadvantages often accumulate through childhood and adulthood. More than ever before, individuals coming from a poor background are likely to experience occupational disadvantage. 

child centres have been closed by local governments across the country since $2009 .{ }^{23}$ These centres offered support for children from disadvantaged backgrounds. Given that the North has a higher concentration of children living in poverty, the Northern regions are likely to be particularly affected by these measures.

\section{Industrialisation and deindustrialisation}

necessarily so straightforward. A study carried out by Law and Morris in 1998 investigated why mortality was higher in poorer areas and more so in Northern areas of England and Wales. ${ }^{24}$ It built on previous research which had demonstrated that areas in general with similar levels of deprivation and socio-economic characteristics report similar health outcomes. Law and Morris found that rural areas and prosperous English authorities had the lowest deprivation and highest life expectancies, urban fringe and coast and service local authorities reported average performance, but mining, manufacturing and industry (or former mining and manufacturing areas) had 
the lowest life expectancies and highest levels of deprivation. London was an exception with high and low life expectancies. The most deprived areas with the lowest life expectancy could be found in the North, North East, but also in London, particularly in East London. While the link between deprivation and ill health was clearly demonstrated, those living in inner cities and particularly manual workers or former manual workers in manufacturing and mining sectors, seemed to be particularly predisposed towards poor health. The North West was reported to have by far the lowest life expectancy. While it fits the socio-economic model, having some very deprived neighbourhoods, it is not the least deprived region in the country. In fact, mining, manufacturing and industry authorities report lower life expectancies than predicted by their levels of deprivation. Research has shown that there may be a direct link between the social conditions in which an individual's parents or grandparents lived and their own heath. Therefore, exposure to pollution in industrial areas might have a significant effect on subsequent generations. ${ }^{25}$

\section{A New Health Deal for the North?}

Considering the wealth of research on the issue of health inequalities and their causes, the State has been slow to address the problem.

\section{Government policy to mitigate health inequalities}

The very first government publication on health inequalities was the Black Report, commissioned by James Callaghan's Labour government in 1977 and published just after the election of the Conservative government under Margaret Thatcher in 1980 looking at cohorts from the 1950s to the 1970s and taken from different environmental settings. It showed that health inequalities were widening and it pointed to the link between social deprivation and health inequalities. However, no action was taken by the Conservative government on these issues. It was only in 1998 with the publication of the Acheson report that health inequalities were given real attention. ${ }^{26}$

New Labour developed a health inequality strategy which was heralded as one of the first, most highly developed and well-funded strategies among European countries to deal with health inequalities. It was a far-reaching strategy which went beyond the realm of health and included raising living standards, improving school nutrition and housing insulation, higher benefits and pensions, more spending on education and urban generation as well as increased spending on health care. Targets were set to reduce infant mortality and life expectancy inequalities by $10 \%$ by $2010 .{ }^{27} \mathrm{~A}$ total of 20 billion pounds was allocated to reduce health inequalities, an area approach was taken to deal with disparities and a spearhead group created comprising 70 local authority areas reporting the worst health and deprivation in the country. Higher budgets and targets were established. These areas were primarily in the North, the West Midlands and parts of London. While there is no doubt that New Labour's specific focus on health inequalities for the first time in the history of England was a sound initiative, and specifically targeting Northern areas suffering from deprivation and ill health, there were a number of weaknesses in the policy approach. While there were targets for reducing inequalities in life expectancy and infant mortality, no policies directly addressed income inequality, working conditions or excessive alcohol consumption. 
Many of the policies were aimed at improving access to treatment but not inequalities in access to healthcare. A number of the policies were interlinked with other areas indirectly influencing health such as education, but for which it was impossible to establish the impact on health when considering policy effectiveness. Targets were chosen without first taking into consideration the policies which would help achieve such targets. Unfortunately, they were not met. All areas, including the spearhead groups, did see life expectancy rise and infant mortality decrease; however, levels of inequalities in health were not reduced because the spearhead groups simply improved in line with the general population. ${ }^{28}$

The strategy came to an end in 2010 under the Conservative/Liberal Democrat coalition government. Nevertheless, the Marmot review published in 2010, following the implementation of the biggest austerity cuts by the government since the Second World War, underlined that reducing health inequalities remained an important issue, not only to uphold the public good (what the report refers to as a strong social justice case) but also economically, with health costing over 30 billion a year in lost productivity and welfare/health costs ${ }^{29}$ Following the 2012 Health and Social Care Act, the government allocated a ring-fenced public health budget to local authorities to devote to poverty-related health needs, totaling $3 \%$ of local government expenditure. However, at the same time, the core local budget was cut by $30 \%$. This was therefore insufficient to tackle health inequalities. Welfare reform, with cuts to local budgets totalling 5.2 billion pounds, has also led to a large financial loss for local economies. ${ }^{30}$

Given the links between health and deprivation, the proposal to boost economic growth in the North of England by the 2010-15 coalition government and 2015-20 Conservative government under the framework of the "Northern Powerhouse" has been seen as a way of indirectly improving health by promoting economic and social wellbeing. The aim is to develop the "Core Cities" of Manchester, Liverpool, Leeds, Sheffield and Newcastle and reposition the UK economy away from London and the South East by strengthening transport links, investment in science and innovation and devolution. More specifically, devolving power to these regions is expected to help Northern regions to manage health care at the local level. In April 2016, Greater Manchester was the first English region to take control of health care spending. Indeed, 10 boroughs, 15 NHS trusts and 12 Clinical Commissioning Groups became jointly responsible for a $£ 6$ billion a year health and social care budget in this region. ${ }^{31}$ The outcomes of such policies are yet to be seen, but cuts to the local authority budgets that manage some areas of primary care and the lower rise in health expenditure means that the budget of 28 billion pounds is unlikely to be sufficient to tackle the complex health challenges in the region. Nevertheless, the role of health care providers remains crucial to address the problems of ill health in the Northern regions.

\section{The role of the National Health Service (NHS)}

The disbandment of government-led initiatives to mitigate health inequalities and the inability to create a real health policy for the North despite the rhetoric, has meant that the NHS is under increasing pressure to fight against health inequalities. In terms of poverty reduction, the distributive effects of public transfers for health are massive. According to Buck and Jabbal, without the provision of free health care, England would be second only to Spain on income inequality. By making health payments in kind, income inequalities are reduced by $13 \%$, which means that England ranks above Ireland 
and Italy, where rationing of health services has been much more significant. ${ }^{32}$ The Acheson report underlined how equity - the principle of matching needs and services was a founding principle of the NHS ${ }^{33}$. The NHS also plays a role as a major regional employer and is, in fact, the biggest employer in Europe. It counters poverty by employing not only medical and related staff but also one million non-medical staff. An increasing number of NHS trusts are signing up to pay the living wage: Wiltshire Ambulance Trust, Barts Health NHS Trust, the Royal College of Midwives, Derbyshire Community Health Services, and the Chartered Society of Physiotherapy. There are many schemes in the NHS to take on the disadvantaged and long-term unemployed. Guy's and St Thomas's Foundation Trust, for example, runs a range of programmes, including a "get into work with the NHS" scheme with the Prince's Trust, which targets Not in Employment, Education or Training (NEETs) aged 16-to-24. ${ }^{34}$ Social determinants of health inequalities are important to understand and act on through employment and social schemes.

There have been increasing efforts to understand health inequalities and develop a strategy and policies to narrow the gap in health performance within the NHS. It is generally accepted that Britain's National Health Service provides universal coverage and upholds the notion of equal access to health care. However, the impact on overall inequality reduction of health care is not as significant as might be hoped. Researchers at the Centre for Health Economics, University of York, carried out a longitudinal study for the period 2004/5 to 2011/12 and measured slope indices of inequality in four indicators: patients per family doctor, primary care quality, preventable emergency, hospital admissions and mortality from conditions considered amenable to health care. They noted larger absolute improvements on all indicators in more-deprived neighbourhoods (which we have established are particularly concentrated in Northern England). By 2011/2012 inequalities in primary care supply and quality were almost eliminated, but socio-economic inequality was still associated with 158,396 preventable hospitalisations and 37,983 deaths amenable to health care. The authors concluded that the NHS did substantially reduce socio-economic inequalities in primary care access and quality but only made modest reductions to health care outcome inequalities..$^{35}$ Other research has shown that between 2001 and 2011, the government's health inequalities policy to increase resources allocated to deprived areas did reduce absolute health inequalities from causes amenable to health care. It has been estimated that each additional $£ 10 \mathrm{~m}$ of resources allocated to deprived areas led to a reduction of 4 deaths in males per 100,000 (3.1 to 4.9) and 1.8 deaths of females per 100,000 (1.1 to 2.4). 36

Unfortunately, as we mentioned previously, such initiatives and investment have been recently axed. Inequalities in health care remain because there is a so-called "inversecare law" ${ }^{37}$ with good medical care in areas where there is less need. More affluent groups tend to use specialist hospital services more than lower income groups. Moreover, since the implementation of austerity measures in 2010, the rise in health expenditure has slowed down and NHS resources allocated to health inequalities policy abolished, hitting the poorest areas of the North hardest. The transfer of a certain number of public health responsibilities to local government has reduced the role of the NHS in tackling health inequalities. Transferring responsibilities from Primary Care Trusts (PCTs) to Clinical Commissioning Groups (CCGs) ${ }^{38}$ has also meant that health inequalities are not necessarily focused on in the same way. Under this new framework, 
quality of health services seems to be of major importance. Integrating health and social care services has also been their priority rather than targeting certain populations.

Yet recent figures released by NHS England support early findings by the Black report which showed that intraregional differences in health care provision may be stronger than regional divides ${ }^{39}$. NHS CCG figures showed for example that patients with dementia, diabetes and learning disabilities received variable care depending on the locality in which they lived. More than half (57\%) of CCGs in England were found to be not performing well enough on dementia, with $71 \%$ classed as "needs improvement" for diabetes care and $92 \%$ for people with learning disabilities. A total of 149 out of 209 CCGs were reported as needing to improve care for diabetes patients..$^{40}$ The Centre of Health Economics at the University of York has argued that health service provision does not necessarily conform to a clear North-South divide. Researchers at this centre analysed the performance of CCGs, establishing indicators focused on emergency hospitalisation for patients with long-term conditions such as dementia, diabetes, respiratory and cardiovascular diseases, which previous research has shown can be reduced by more effective primary care and outpatient care. The researchers contend that some Clinical Commissioning Groups are better at tackling health inequalities irrespective of whether they are based in the North or South. The Liverpool CCG appears on the worst list but so does Islington. On the other hand, both Portsmouth and Stoke-on-Trent CCGs are seen as the best performers. All these belong to the most deprived neighbourhoods in the country. South Cheshire, a wealthy area, performs badly, while East Surrey performs well. ${ }^{41}$ While the picture is far from clear, it is however worth noting that 8 of the 10 worst performing CCGs in this study are located in the North. The best performing CCGs are still largely located in the South such as City and Hackney in London, followed by Fareham and Gosport, East Surrey, Crawley and the Isle of Wight. Tower Hamlets in London was seventh. ${ }^{42}$ 


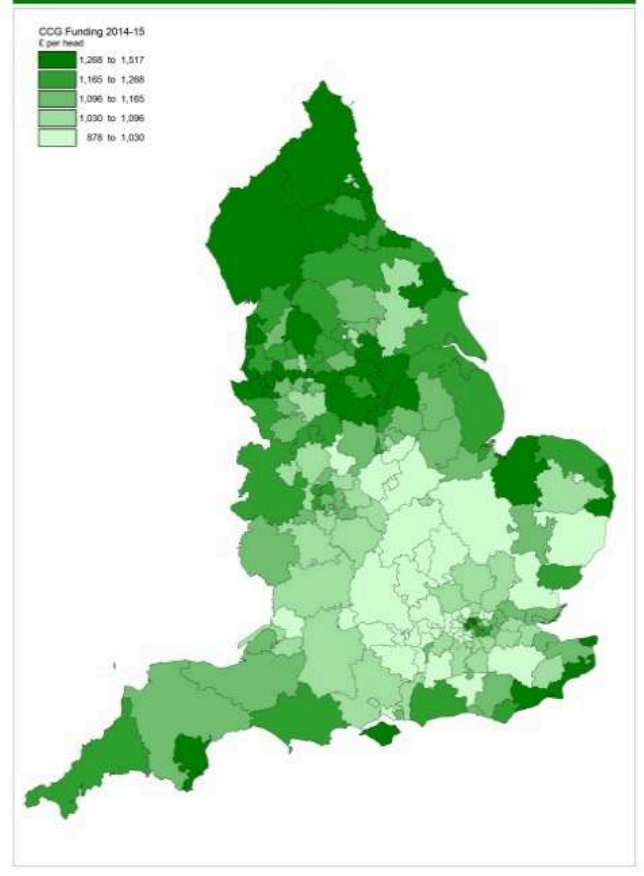

Source: House of Commons, 201443 still a clear North-South divide in health outcomes. There appears to be a definite albeit complicated link between deprivation and poor health performance. Nevertheless, higher funding is granted to those regions that suffer from poorer health outcomes in the North. Yet, significant interregional and intraregional differences in the provision of health care are apparent. The levelling of such disparities is a challenge that health care providers will have to face in the future to ensure the sustainability of the current health system in England.

Socio-economic inequalities in preventable hospitalisation and amenable mortality are not only the result of inequalities in the supply of primary and hospital care, they are also due to socio-economic-related differences and lifestyle. In sum, public health care provision is important to reduce inequalities but there are many other wider social factors and institutional factors to take into consideration. 

year ${ }^{44}$, more funds should be strategically invested to mitigate health inequalities. Greater investment in education, skills, health, housing and infrastructure is needed and this clearly does not seem to be a priority for central government faced with the current climate of austerity. The fact that health is related to economic growth and wealth in the regions suggests that the economy of the North needs to grow faster than the rest of the country and greater investment should be made in infrastructure, investment in research, investment in Small and Medium-Sized Enterprises (SMEs), etc. to achieve equal health outcomes. The lack of investment in infrastructure in the North is a barrier to growth. In addition, to ensure that health inequalities are reduced, strong leadership to target these problems is required. privileged groups and the lack of capabilities. He puts much emphasis on empowerment in communities. The power of individuals and communities is indeed central to reducing health inequalities. The Nobel Prizewinning economist James Heckman $^{46}$ also shows how early investment can significantly increase the rate of economic return, which will have a knock-on effect on health and wellbeing. It is not just about providing financial support but investing in early years, in terms of education, health and support for children that will make a difference to the health of the North in years to come.

\section{BIBLIOGRAPHY}

Acheson, David, Public Health in England: The Report of the Committee of Inquiry into the Future Development of the Public Health Function (London, HMSO 1998).

Asaria, Miqdad et al., "How a universal health system reduces inequalities: lessons from England", Journal of Epidemiology and Community Health 70:7 (2016), pp. 637-43.

Bartley, Mel, Health Inequality: An Introduction to Theories, Concepts and Methods (Cambridge, Polity Press, 2004).

Barr, Ben, "The impact of NHS resource allocation policy on health inequalities in England 2001-11: longitudinal ecological study", British Medical Journal 348 (2014), Available at: <https:// www.bmj.com/content/348/bmj.g3231>.

Bartley, Mel and Blane David, "Inequality and social class" in Graham Scambler (ed.) Sociology as Applied to Medicine (Elsevier Limited, 2008), pp.115-33.

Black, David, Inequalities in Health: Black Report (London, Pelican Series, Penguin Books, 1982).

Buchan, Iain, Evangelos Kontopantelis, Matthew Sperrin, Tarani Chandola and Tim Doran, “ North-South disparities in English mortality 1965-2015: longitudinal population study”, Journal of Epidemiology \& Community Health 71:9 (2017), pp. 928-936.

Buck, David and Jabbal, Joni, Tackling poverty: Making more of the NHS in England, (London, King's Trust, 2013).

Revue Française de Civilisation Britannique, XXV-2 | 2020 
Department of Health, Tackling Health Inequalities: Ten Years On (London, HMSO, 2009).

Dorling, Danny, Unequal Health: The Scandal of our Times (Bristol, The Policy Press, 2013).

Gregory, Ian R. "Comparisons between geographies of mortality and deprivation from the 1900s and 2001: spatial analysis of census and mortality statistics", British Medical Journal (10 September 2009), p. 339.

Heckman, James, Giving Kids a Fair Chance (Cambridge, MA, MIT Press, 2012).

Inquiry Panel on Health Equity for the North of England, Due North: The Report of the Inquiry on Health Equity for the North (Liverpool, University of Liverpool and Centre for Local Economic Strategies, 2014).

Law, Malcom and Morris, Joan, "Why is mortality higher in poorer areas and in more northern areas of England and Wales?", Journal of Epidemiology and Community Health 52:6 (1998), pp. 344-352

Le Grand, Julian, The Distribution of Public Expenditure: the Case of Health Care (Paris, Economica, 1978).

London School of Hygiene and Tropical Medicine, "The Whitehall Study archive collection". LSHTM Archives. August 2011, available at: < http://calmview.lshtm.ac.uk/calmview/>.

Marmot, Michael, Fair Society, Healthy Lives Marmot Review, Strategic Review of Health Inequalities, (London, Department for International Development, 2010).

Morris, Stephen, Devlin, Nancy and Parkin, David, Economic Analysis in Healthcare (Chichester, John Wiley \& Sons, 2009).

Pidd, Helen, “Greater Manchester begins £6bn 'devo health' experiment," The Guardian, 1 April 2016.

Sen, Amartya, Inequality Reexamined. (Oxford: Oxford University Press, 1992).

The Sutton Trust, “1,000 Children's centres lost since 2009”. Available at: <https:// www.suttontrust.com/newsarchive/1000-childrens-centres-closed-since-2009>.

Wilkinson, Richard G. and Pickett, Kate E., Health and Inequality: Major Themes in Health and Social Welfare (Abingdon, Oxon, UK, New York, New York, Routledge, 2008).

Wilkinson, Richard G., The Impact of Inequality: How to Make Sick Societies Healthier (London, Routledge, 2005).

Wilkinson, Richard G. and Marmot, Michael, The Solid Facts (Copenhagen, World Health Organization, Regional Office for Europe, 2003).

Wilkinson, Richard G. Kawachi, Ichirō and Kennedy, Bruce P., The Society and Population Health Reader, Vol. 1 (New York, New Press, Distributed by W.W. Norton, 1999).

Wilkinson, Richard, G., Unhealthy Societies: The Afflictions of Inequality (London; New York, Routledge, 1996).

Wilkinson, Richard, G., Unfair Shares: The Effects of Widening Income Differences on the Welfare of the Young (Ilford, Barnardos, 1994).

Wilkinson, Richard G. and Quick, Allison, Income and Health (London, Socialist Health Association, 1991).

Wilkinson, Richard G., Class and Health: Research and Longitudinal Data (London, New York, Tavistock Publications, 1986). 


\section{NOTES}

1. Michael Marmot, Fair Society, Healthy Lives Marmot Review, Strategic Review of Health Inequalities (London, Department for International Development, 2010).

2. When we refer to the North, we are referring to the Northern regions of England: Yorkshire and the Humber, the North West and the North East.

3. Stephen Morris, Nancy Devlin and David Parking, Economic Analysis in Healthcare (Chichester, John Wiley \& Sons, 2009).

4. Department of Health, Equity and Excellence: Liberating the NHS, Cm 7881 (London, HMSO, 2010).

5. ONS, "Health state life expectancies, UK: 2013 to 2015", 2016, available at <https:// www.ons.gov.uk/releases/healthstatelifeexpectanciesuk2013to2015>.

6. In statistics, a $95 \%$ confidence interval (CI) is a range of values that one can be $95 \%$ certain contains the true mean of the population.

7. Iain E. Buchan, Evangelos Kontopantelis, Matthew Sperrin, Tarani Chandola and Tim Doran, "North-South disparities in English mortality 1965-2015: longitudinal population study”, Journal of Epidemiology \& Community Health 71:9 (2017), pp. 928-36.

8. Ibid.

9. Office for National Statistics, "Statistical bulletin: Healthy life expectancy at birth and age 65 by upper tier local authority and area deprivation: England, 2012 to 2014", 2016, available at <https://www.ons.gov.uk/peoplepopulationandcommunity/healthandsocialcare/

healthandlifeexpectancies/bulletins/

healthylifeexpectancyatbirthandage65byuppertierlocalauthorityandareadeprivation/

england2012to2014>.

10. Inquiry Panel on Health Equity for the North of England, Due North: The Report of the Inquiry on Health Equity for the North (Liverpool, University of Liverpool and Centre for Local Economic Strategies, 2014).

11. Richard G. Wilkinson and Kate E. Pickett, Health and Inequality: Major Themes in Health and Social Welfare (Abingdon, Oxon, UK, New York, New York, Routledge, 2008).

Richard G. Wilkinson, The Impact of Inequality: How to Make Sick Societies Healthier (London, Routledge, 2005).

Richard G. Wilkinson and Michael Marmot, The Solid Facts (Copenhagen, World Health Organization, Regional office for Europe, 2003).

Richard G. Wilkinson, Ichirō Kawachi and Bruce P. Kennedy, The Society and Population Health Reader, Vol. 1 (New York, New Press, Distributed by W.W. Norton, 1999).

Richard, G. Wilkinson, Unhealthy Societies: The Afflictions of Inequality (London; New York, Routledge, 1996).

Richard, G. Wilkinson, Unfair Shares: The Effects of Widening Income Differences on the Welfare of the Young, (Ilford, Barnardos, 1994).

Richard G. Wilkinson and Allison Quick, Income and Health (London, Socialist Health Association, 1991).

Richard G. Wilkinson, Class and Health: Research and Longitudinal Data (London, New York, Tavistock Publications, 1986).

12. Michael Marmot, Fair Society, Healthy Lives Marmot Review, op.cit.

13. David Buck, "How Healthy are We", The King's Fund (Powerpoint Presentation), 2014. Available at: <https://www.kingsfund.org.uk/audio-video/how-healthy-are-we>.

14. Mel Bartley and David Blane, "Inequality and social class" in Graham Scambler (ed.) Sociology as Applied to Medicine (Elsevier Limited, 2008), pp. 115-33. 
Mel Bartley, Health Inequality: An Introduction to Theories, Concepts and Methods (Cambridge, Polity Press, 2004).

15. London School of Hygiene and Tropical Medicine, "The Whitehall Study archive collection". LSHTM Archives. August 2011, available at: <http://calmview.lshtm.ac.uk/calmview/>

16. Malcom R. Law and Joan Morris, "Why is mortality higher in poorer areas and in more northern areas of England and Wales?", Journal of Epidemiology and Community Health 52:6 (1998), pp. 344-352.

17. The first report to study inequalities in England, published in 1980.

18. Inquiry Panel on Health Equity for the North of England, op. cit.

19. Michael Marmot, op. cit., p. 20.

20. Danny Dorling, Unequal Health: The Scandal of our Times (Bristol, The Policy Press, 2013).

21. Inquiry Panel on Health Equity for the North of England, op. cit.

22. The following link gives more details on these cuts:

https://www.theguardian.com/news/datablog/2013/apr/01/every-welfare-cut-listed.>.

23. The Sutton Trust, "1,000 Children's centres lost since 2009”. Available at: <https:// www.suttontrust.com/newsarchive/1000-childrens-centres-closed-since-2009>

24. Malcom R. Law and Joan Morris, op.cit.

25. Ian R. Gregory "Comparisons between geographies of mortality and deprivation from the 1900s and 2001: spatial analysis of census and mortality statistics", British Medical Journal (10 September 2009), p. 339.

26. David Acheson, Public Health in England: The Report of the Committee of Inquiry into the Future Development of the Public health function (London, HMSO, 1998).

27. Department of Health, Tackling Health Inequalities: Ten Years On (London, HMSO, 2009).

28. Ibid.

29. Michael Marmot, op.cit., p. 16.

30. Inquiry Panel On Health Equity For The North Of England, op. cit.

31. Helen Pidd, “Greater Manchester begins £6bn ‘devo health’ experiment," The Guardian, 1 April 2016.

32. David Buck and Joni Jabbal, Tackling poverty: Making more of the NHS in England (London, King's Trust, 2013).

33. David Acheson, op. cit.

34. Ibid.

35. Miqdad Asaria et al., "How a universal health system reduces inequalities: lessons from England", Journal of Epidemiology and Community Health, 70:7 (2016), pp. 637-43.

36. Ben Barr, "The impact of NHS resource allocation policy on health inequalities in England 2001-11: longitudinal ecological study", British Medical Journal, 348 (2014).

Available at: <https://www.bmj.com/content/348/bmj.g3231>.

37. The term was first used by Tudor Hart, a GP in Wales (see Hart, Tudor J. 'The inverse care law', Lancet 1, 7696: 1971, pp. 405-412). Julian Le Grand supported Hart's analysis after combining data on the utilisation of services and finding that higher social groups tended to benefit more from health care than lower social groups (see Julian Le Grand, The Distribution of Public Expenditure: The Case of Health Care (Paris, Economica, 1978)).

38. Primary Care Trusts (PCTs) were NHS administrative bodies created in 2001. PCTs were responsible for commissioning primary, community and secondary health services from providers. PCTs held around 80 per cent of the total NHS budget. On 31 March 2013 these bodies were abolished under the Health and Social Care Act 2012 and their responsibilities transferred to Clinical Commissioning Groups (CCGs) and the local authorities.

39. David Black, Inequalities in Health: Black Report (London, Pelican Series, Penguin Books, 1982). 
40. The Guardian, "'Postcode lottery' revealed in NHS care", Guardian Online, 8 September 2016. Available at < https://www.theguardian.com/society/2016/sep/08/ postcode-lottery-revealed-in-nhs-care>.

41. Centre For Health Economics, "NHS adopts Centre for Health Economics Clinical Commissioning Group health inequality indicators." University of York, Centre for Health Economics, 16 August 2016. Available at < https://www.york.ac.uk/che/news/ 2016/nhs-adopts-che-ccg-indicators/>.

42. Ibid.

43. House of Commons, "New CCG funding allocations -mapped", 27 January 2014. Available at: <https://secondreading.uk/author-john-wood/new-ccg-funding-allocations-mapped/>.

44. Inquiry Panel on Health Equity for the North of England, op. cit.

45. Amartya Sen, Inequality Reexamined (Oxford, Oxford University Press, 1992).

46. James Heckman, Giving Kids a Fair Chance (Cambridge, MA, MIT Press, 2012).

\section{ABSTRACTS}

Tackling health inequalities has become one of the key focuses of government health policy over recent years. Health inequalities refer to differences between people or groups due to social, geographical, biological or other factors in terms of life expectancy and healthy life expectancy According to the 2010 Marmot review, not only is there a strong social justice case for reducing health inequalities, but also an economic one, since it is estimated to cost over $£ 30$ billion a year in lost productivity and welfare costs. Health coverage is universal in England and close to full coverage in many areas of public health. The founding principles of the NHS are that public health services should be free at the point of use and that health inequalities are undesirable because they are unfair or unjust.

Yet, despite universal coverage of health services and the equity principles behind public health in the UK, nowhere is the North-South divide more apparent than in the area of health. Since the 1960s, the South has consistently outperformed the North in terms of health outcomes in all areas (life expectancy, ill health, chronic disease...). Poor health is associated with socioeconomic status, which is one of the main reasons why the North is at a disadvantage, with a higher number of neighbourhoods suffering from multiple deprivation. This paper considers health inequalities between the North and South and reviews policy implemented since the late 1970s to improve health service delivery in the North of England. In particular, it considers to what extent public policy has mitigated health inequities there.

La lutte contre les inégalités en matière de santé est devenue l'un des axes majeurs de la politique de santé du gouvernement britannique au cours des dernières années. Ces inégalités marquent des différences entre des personnes ou des groupes en raison de facteurs sociaux, géographiques, biologiques ou autre. Selon le rapport Marmot de 2010, il est non seulement nécessaire de réduire les inégalités de santé pour défendre le bien public (ce que le rapport dénomme « la justice sociale »), mais aussi pour des raisons économiques. La santé coûte plus de 30 milliards de livres sterling par an en perte de productivité et en coûts sociaux. La couverture de santé est universelle en Angleterre. Selon les principes fondateurs du NHS, les services de santé publique 
doivent être gratuits au point d'utilisation et les inégalités de santé sont indésirables parce qu'elles sont injustes.

Pourtant, malgré une couverture universelle des services de santé et les principes d'équité de la santé publique au Royaume-Uni, la fracture Nord-Sud est nulle part ailleurs plus évidente que dans le domaine de la santé. Depuis les années 1960, les indicateurs de santé sont meilleurs dans le Sud que le Nord, et ceci dans tous les domaines (espérance de vie, état de santé, maladies chroniques, ...). Les problèmes de santé tendent à dépendre fortement des conditions socioéconomiques, ce qui constitue l'une des principales raisons pour lesquelles le Nord, avec un nombre important de localités pauvres, est désavantagé par rapport au sud. Cet article compare les inégalités de santé entre le Nord et le Sud et analyse la politique de santé mise en place depuis la fin des années 1970. En particulier, il tente d'évaluer l'efficacité des politiques publiques en matière de lutte contre les inégalités dans le Nord de l'Angleterre.

\section{INDEX}

Mots-clés: Nord de l'Angleterre, inégalités de santé, pauvreté, prestation des services de santé Keywords: North of England, health inequalities, deprivation, health service delivery

\section{AUTHOR}

\section{LOUISE DALINGWATER}

HDEA (EA 4086), Sorbonne-Université.

Louise Dalingwater est professeur en civilisation britannique et anglais économique au département de Langues Etrangères Appliquées à Sorbonne-Université, Paris. Ses recherches portent sur la contribution des services à l'économique britannique. Elle est auteur de plusieurs ouvrages dont « Les services britanniques au 21e siècle : une étude interdisciplinaire (Presses Universitaires de Nancy, 2015), avec Catherine Coron de « Wellbeing: Challenging the AngloSaxon Hegemony » (Presses Sorbonne Nouvelle, 2017) et de nombreux articles sur les services publics. 